\title{
The Challenges of Instrumentalist Approach to the Involvement of African Women in Peacemaking and Peacebuilding
}

\author{
Funmilayo Idowu Agbaje, Ph.D \\ Institute for Peace and Conflict Studies \\ University of Ibadan, Ibadan \\ Nigeria.
}

\begin{abstract}
In recent times, most arguments put forward in support of a gendered approach to peacemaking and peacebuilding from diverse set of scholars from a variety of disciplines, are instrumental in their approaches. African peace scholars and actors tend to perceive and portray women as instrumental in bringing about sustainable peace, and focusing narrowly on what women can do for peace neglecting the issue of what peace can do for women. The range of peace activities within the overall gendered approach, even a purported genuine approach as understood by the United Nations and other national and International peace community actors often fail to build a sustainable peace as it does not adequately address the fundamental socio-political and economic inequalities created by the global neoliberal structure which also perpetuate violence and conflict. Oftentimes, African women are defined through the lens of their motherly and caregivers' roles while providing the link between these roles and their peace attributes. Despite the fact that these notions are true, the challenge remains in the ways those positive attributes are used as tools to undermine the multi-farious involvement of women in peace process. This paper will examine some of the long-standing instrumentalist approaches to African women's involvement in Peacemaking and Peacebuilding processes by discussing extant literatures and also focus on some case studies within African continent. The ways some of these approaches have essentialised women's roles in the society and the challenges arisen therefrom will also be discussed.
\end{abstract}

Keywords: Challenges, Instrumentalist Approach, African Women, Peacemaking, Peacebuilding

\section{Introduction}

In the history of Africa, women often throw themselves into peace processes with enormous courage and determination. Women, as torchbearers of peace, are making a difference in hotspots of every region of Africa. African women have joined forces, and work together as advocates for peace in many African states such as Liberia, Rwanda and Sierra-Leone. Women's Peace agencies had ventured into the most treacherous conflictridden interiors to protest against the war and to negotiate with the government. For generations, women have served as peace educators. They have proved instrumental in building bridges rather than walls and there are many stories that remain to be told about women from all walks of life, which are making a quantum leap from lives in the private sphere to leading the way in reshaping their societies. For example, during crisis in Liberia in the year 2007, women of the ManoRiver region (Liberia, Guinea and Sierra Leone) came together to form the Mano River Women's Peace Network (MARWOPNET). Their voices became so powerful that they were invited to the sponsored peace talks on Liberia, and was later asked to be one of the signatories to the peace agreement. This shows that women unseen and unsung works had brought peace to many troubled African nations. Women, therefore, are potent instruments of peacemaking and peacebuilding.

The terms 'peacemaking' and 'peacebuilding' represent two distinct categories of United Nations' intervention in conflict situations. While Peacemakingis a process establishes effective institutions for conflict management by enhancing a culture of peace and pursuing preventive diplomacy, peacebuilding is understood as a comprehensive concept that encompasses, generates, and sustains the full array of processes, approaches, and stages needed to transform conflict toward more sustainable, peaceful relationships (Lederach, 1997). The two terms might be distinct in terminology but found common grounds in operations because they involve a wide range of activities that both precede and follow formal peace accords. Metaphorically, peace is therefore, seen not merely as a stage in time or a condition. It is a dynamic social construct. 
Indeed, it is important to say that peace does not mean absence of war. Peace is building relationships that will bring about diversity and economic growth among people, since no family or community can develop and grow if peace is not established. Peace is associated with patience, utterances, understanding, sympathy, apologies, love, togetherness, unity, good behaviour, reconciliation, trust, tolerance, forgiveness, advice, happiness, dialogue, respect, negotiation, justice and truth. The fact that many women are natural peacemakers been acknowledged by many scholars (Agatha, 2006 \& Anderlini, 2000). Too often, women's peace roles are played out as passive and behind the scenes.

The call for women active participation by the United Nations Security Council Resolution (S/RES/ 1325) reaffirms the important role of women in the prevention and resolution of conflicts, peace negotiations, peacebuilding, peacekeeping, humanitarian response and in post-conflict reconstruction and stresses the importance of their equal participation and full involvement in all efforts for the maintenance and promotion of peace and security. The Resolution urges all actors to increase the participation of women and incorporate gender perspectives in all United Nations peace and security efforts. This resolution began the revolutionary advocacy on women's involvement in peace processes across African nation. In order to achieve this inclusion, oftentimes, African women are defined through the lens of their motherly and caregivers' roles while providing the link between these roles and their peace attributes. Despite the fact that these notions are true, the challenge remains in the ways those positive attributes are used as tools to undermine the multi-farious involvement of women in peace process. This paper thus examines some of the long-standing instrumentalist approaches to African women's involvement in peacemaking and peacebuilding processes by discussing extant literatures and also focusing on some case studies within African continent. The ways some of these approaches have essentialised women's roles in the society and the challenges arisen there from will also be discussed.

\section{Statement of the Problem}

Noteworthy is the fact that women continue to be scanty during peace talks and when considered, the stakeholders overwhelmingly fail to address structural inequalities and power dynamics which are the foundation of gender discrimination in the first place (Strickland and Duvvury, 2003). Many times, while discussing women's involvement in peacemaking and peacebuilding, actors from a variety of disciplines, with different social and political backgrounds are instrumentalist in their approach, seeing women as instrumental in bringing about sustainable peace, and focusing narrowly on what women can do for peace, neglecting the issue of what peace can do for women. The importance of women's peace agencies are often confined within their primary roles as mothers, pacifiers and caregivers. As true as these notions are, especially in the African context, it has, to a larger extent, denied them access to the broader agenda of peacemaking and peacebuilding (Puechguirbal, 2010). This paper thus outlines some of the challenges posed by these approaches to the range of arguments within the overall women's inclusion in peace processes. Perhaps, the reason a sustainable peace has not been achieved in Africa is because some of the arguments for women active participation in peacemaking and peacebuilding does not adequately address the fundamental economic inequalities created by the socio-political and religious structure which also perpetuate violence and conflict.

\section{Literature Review}

A number of scholars have focused on the image of women in Africa and more specifically, those traits that distinguished them in peace processes. According to Kure (2010), women are more tolerant. They are very supportive to the men and can help in bringing factions together in a community. Traditionally, women are seen as closer to the life-giving earth, associated with fertility and circles. Women as nature, as sexuality, as fertility, as fertility are mythic images deeply embedded in most African cultural psyches (Gnanadason et al., 2005). Indeed, women have been portrayed as peace educators in most African communities (Sudarkasa, 2005). The girls are reared to be docile, obedient and nice (Agatha, 2006). In many places, they are brought up to believe that their role is to serve men, to sacrifice their own needs for the good of the man, for the well-being of the family and community. More than that, women are more concerned about the maintenance of peace within their families in particular and communities at large because, as mothers they bear the brunt of continued disappearance of their children and the violence which destroys their families (Robbin and Judge, 2009). In terms of peace roles, women have been described as facilitators, a good listener and motivator, who provide support to the people within a given community. Women are involved in many different peacebuilding initiatives at the community level, as well as providing day-to-day and emergency support for their communities (Gizelis, 2011). 
Noteworthy are the initiatives undertaken by women in Somalia, Burundi, Liberia and other countries in contributing to the creation of a peaceful and secure environment pointed to their important role as equal partners in securing peace. In Rwanda and Nigeria women had effectively mobilized governments and civil societies to promote dialogue among the warring factions and had given invaluable support to the national peace process. The unanswered question is if these women, after all they have done to ensure peace, would be given sufficient recognition in their country's socio-political affairs when it is constituted. Despite, the fact that Rwanda has laid a good example by increasing the number of women in the parliament to sixty four percent (64\%), the gender gap is still very wide in real-life socio-religious relationships.

Proponents of a gendered approach to peacebuilding and conflict resolution argue that women's involvement in peace missions in higher numbers will have positive effects for women in the countries where missions are stationed, by providing positive examples of female leadership (Bertolazzi, 2010). Furthermore, according to Robbins et al (2003), the leadership styles women typically use can make them better at resolving conflict, as they are inclined to treat dialogues from the perspective of an ongoing relationship- working hard to make the other party a winner in its own and other's eyes. This notion is not far from the existing imbalance that has been mastered over the years, passed from one generation to the other to the extent that it has become a societal norm (Mutunga, 2005).

Apparently, women have played many roles in various African societies throughout history. They are wives, mothers, farmers, labourers, business executive, a teacher, among several other responsibilities and professions which oftentimes, are combined. Almost every society, therefore, has developed definite ideas of what a woman should be and what is proper for women to do (Epstein, 1981). While some focus on overall process, the others focus on the role of women in the process. In ideal peace operations, the two should be inseparable. The overall peace activities should not elude women while attention should be given to those crucial roles played by women during peace processes. Without challenging neoliberal policies which widen social and economic inequalities between African men and women, women would further be disadvantaged, violence would be fomented and the ultimate goal, which is a sustainable and positive peace, will be unattainable. Despite the landmark UNSCR 1325, the resolution has been criticised for ostensibly giving power to western countries to intervene in peace processes around the world on the pretext of protecting women's rights (Aroussi, 2011).

\section{Methodology}

This paper relies on secondary sources of information such as text books, newspaper and journal articles. It is a qualitative study which is based on conceptual, historical and theoretical analysis. It considers women's role in peace-making and peace building from an emic perspective.

\section{Analysis and Discussion}

In many times, African women has been perceived and presented as 'natural peacemakers' and 'peacebuilders'. Consequently, many actors in the international arena concerned with peacemaking and peacebuilding have engaged women in Africa with the expectations that their involvement would enhance the efficiency and effectiveness of peace operations. More so, women's efforts in making and building peace are valuable resources for the development of sustainable, inclusive approaches to peace and security. However, some of these virtues, possessed by the women have been objectified and in most conflict situations used against them. There are significant tensions inherent in advocating for women's involvement in peacemaking and peace building because in many occasions, those agitating for war, exploit the number of themes surrounding the involvement of women (Gibson, 2011) as much as those advocating for peace. Evident in many African cultures is the motherly role conferred on women. An African woman is expected to nurture, provide and protect her family. The mothering nature of African women can also be interpreted in terms of their prerogative in the society at large as a category of people that give and protect life. In peacemaking and peacebuilding operations, this can be defined as an instrumentalist approach, which in overall is concerned with what women can do for peacebuilding and not the reverse. Considering the high rates of vulnerabilities of women before, during and in post-conflict situations, the question that readily comes to kind is why the custodian and givers of peace often suffer the brunt of war the most. Consequently, some scholars argue that the celebration of the Women, Peace and Security agenda and UNSCR 1325 is little more than empty rhetoric (Puechguirbal, 2010). Giventhe antecedence of African women as mothers, especially during the pre-colonial African states and in many post-colonial African traditional settings, one may begin to wonder why women are so denigrated and essentialised during violent conflicts. 
The 'mothers' are defiled, maimed, traumatised and get killed in times of war and the onus still lie on them for adequate peacemaking and peacebuilding after war.

Noteworthy is the fact that a woman's expectation to give relentlessly even at her own discomfort is not alien to many African traditions. An African woman gets married, gives birth to children, nurtures the children, takes care of her husband, takes care of her relatives and is expected to take care of the society at large. Even though she also has the responsibility of taking care of herself, it must not come before she has met the needs of others around her. In the olden days in African societies such as Nigeria, Ghana and Kenya, it was a taboo to violate the women during war. In fact, women in traditional Yoruba kingdoms were revered as mothers that they could go between warring parties to stop a war and nobody dares touch them. However, the challenge in the analysis of recent conflict situations is that actors in conflict as well as peace processes tend to focus on what women can give either for conflict or for peace. Women have specific vulnerabilities and often experience multiple forms of violence during and after conflict, with brutality and frequency reaching new levels in times of conflict and societal breakdown. However, while women are heavily targeted during violent conflict by armed men as objects of victimisation in forms of mass rape, sexual slavery and several other physical assaults aimed at denigrating the opposition and in some cases securing unto the armed men, an offspring, they are, at the same time, expected to facilitate peace at the end of crisis. Furthermore, the imageries of African women as protectors and keepers are supposed to be seen as some of the strong aspects of womanhood in Africa. African women do not only protect lives, they also protect properties. However, the traditional roles of women as protectors rather than strengthening the status of women in Africa had further weakened it. In contemporary African conflicts such as the Boko Haram insurgency in Nigeria, women are being used as human shields against military attacks and forced suicide bombers in order to distract government and international military forces. Women and girls have become the weapon of choice by the Boko Haram group. The Nigerian military has rescued at least 500 women since it began a major offensive against Boko haram's base in Sambisa forest.

In addition, the targeting of African women's bodies has emerged a systematic strategy used during conflict and also, during peacemaking and peacebuilding respectively. Specific forms of violence, especially sexual violence, are used against women in times of conflict. Furthermore, extremely high levels of violence against women had been recorded after the formal cessation of conflict either by the citizens or by the peacekeepers who were supposed to keep the people safe. Suffice to say at this point that African women's bodies had been traditionally used in peace rituals, peace protests and also as archives for peaceful message inscriptions and imagery (Agbaje, 2017). A woman's body is also instrumental to reproduction of life. The complexities of this dilemma is such that while women had used their bodies as instruments of peacemaking and peacebuilding in the history of many African societies, the use of female's body readily come to the fore during conflict times as well. According to Pankhurst, women do not suffer in war because of any intrinsic weakness, but because of their position in the society (Pankhurst, 2000). The issue of raping enemies' women in conflict can be seen as being aimed at men, using a woman's body as a vessel and violating both a man's honour and his exclusive right to sexual possession of his woman as his property (Copelon, 2002). It can also be interpreted as a way of procreating by the warring parties, especially the young men among them. Also, these men are aware of the long term effects of sexual violence, not only to the women but also, to the society at large. Sexual violence destroys families and communities and leaves long lasting effects such as unwanted pregnancies and children, sexually transmitted infections such as HIV/AIDS and Hepatitis. Survivors can be ostracised from society, treated differently by family members, cut off from support networks and denied justice. This can have long-lasting effects on community reconciliation and stabilisation. These are some of the challenges of projecting women's bodies as instrumental to peace. How can a woman give what she does not have?

Over the years, African women's important role as mothers, caregivers and nurturer of the home and the society at large have shaped and better explains their roles in reconciling conflicting parties. Women, therefore, have been described as natural peacemakers (Ruddick, 1989). Nevertheless, the portrayal of African women as pacifiers, has somehow affected the peace of women. Insurgents such as Boko Haram has played on the common perception of women as non-violent to effortlessly mainstream women into their operations, using them to gather intelligence, as recruiters, and promoters of radical ideologies to indoctrinate abductees and other converts in Boko Haram enclaves. In fact, the sects have allegedly preyed on women's grievances relating to marginalisation, inequality, and alienation to recruit more women into its folds. In other cases, women are unwilling perpetrators and are forced into becoming suicide bombers, sex slaves, and forced labourers. 
Specifically, in peacebuilding contexts, women are often portrayed as a set of people in need of protection. In African states' patriarchal framework, women's vulnerability has been emphasized rather than their peace agency. In Puechgurbal's words 'Women are not more vulnerable per se in times of war; they are made more vulnerable because of pre-existing inequalities in so-called peaceful societies (Puechguirbal, 2010).Furthermore, painting women purely as victims during conflict can obscure women's agency and undermine the positive work which some women do in resisting conflict and building peace(Strickland and Duvvury, 2003). Noteworthy is the fact that women are also involved in supporting conflict and agitating violence, as well as directly participating in combat(Pankhurst, 2000, 2008). There were women combatants during outbreak of crisis in Rwanda, Uganda, Sierra-Leone and in Liberia. In order to support this argument, Meintjes, Pillay and Turshen posit thus: 'During the transition from war to peace, or from military dictatorship to democracy, the rhetoric of equality and rights tends to mask the reconstruction of patriarchal power, despite recent emphasis on women's human rights (Meintjes etal, 2001).

This is usually more obvious in post-conflict activities aimed at restoring the society to a peaceful status-quo. During this time, gender stereotypes are often emphasized. In most cases, women's traditional roles as wives and mothers are being extolled, while their wartime roles as combatants, warlords and defenders, which might have given them greater freedom or a wider diversity of roles, are ignored. For this reason, scholars, highlight structures of patriarchy as a central reason why societies continue to relapse to violent conflicts (Puechguirbal, 2010). These arguments advocate a fundamental shift in men to women power relations, and a transformation post-conflict experience of both. Ignoring women's complicity in violent conflict could lead to false assumptions about the potential role of women in making peace.

Moreover, according to Onslow and Schoofs (2010), categorizing African women as one without highlighting the differences between them in forms of class, race and religion, have the potential of hiding a wealth of different experiences because no woman lives in the single dimension of her sex. For instance, wealthy women in the society will experience conflict and its attendant consequences in a very different way from the less privileged which are often the majority in most African nations. They are usually too poor to emigrate when they are threatened with violence. Furthermore, their voices are not easily heard during formal peace. The challenge, therefore, is that while agitating for women's involvement in peace activities, women at the grassroots are often glossed over.

Despite their peacebuilding efforts, the under-representation of women at the peace table continues to be much more marked than in other areas, with women's participation remaining a largely unfulfilled target of UNSCR 1325 (Diaz, 2010). It is men who continue to dominate the formal roles in the peacebuilding process. In order to stop all discriminatory attitudes against women in peacemaking and peacebuilding practices, therefore, the existing gender norms should be adequately challenged and transformed. In addition, the attendant power imbalances between both sexes should be reconstructed (Enloe, 2005). In essence, in order for an impressive contributions of women in Africa to be evident in peacemaking and peacebuilding, there is a pressing need to deconstruct and reconstruct some of the long-standing arguments surrounding the involvement of women in peace process that are actually, in most cases, stemming from the instrumentalist mentality that constitutes a larger sum of African cultural beliefs about the position of a woman in the scheme of operations. Nevertheless, real change takes time hence it takes processes and procedures to get the African generations to circle back and address changes that were left undone.

\section{Conclusion}

Evidently, the implementation of the United Nations Security Council Resolution (UNSCR 1325) accords has been largely ineffective and a sustainable peace has not been built in African nations, especially in those nations that had experienced violent conflicts or those still in the middle of crisis. Thus despite initial praise for the peace resolution, the mainstream instrumentalist approach to the involvement of women in peace processes appeared to be superficial hence the need for a more fundamental analysis which addresses the deep rooted structural inequalities between male and their female counterparts. Indeed, it is highly problematic to assume the primacy of any one component of a person's social identity over another. Dogmatically, there is no denying the fact since the United Nations' call for women's involvement at all levels of peace agenda, there has been a marginal increase in the number of women involved in formal peace talks, protection of women and girls from sexual violence has become a priority and women's peace coalitions have grown in strength and are now increasingly able to get 
women's concerns on the agenda of peace talks across Africa nations. However, positive examples do not amount to system change. The evidences point to the fact that women's participation in formal peace processes still remains low. Their contributions are consistently devalued. Sexual and gender-based violence is endemic, and issues concerning African women continue to be treated as marginal to the main peace agenda. Thus, the gap between policy and actual implementation is still wide. In conclusion, while protecting women from conflicts and violence would remain a priority for the international community, it is also very expedient that emphasis are laid on the role of African women as leaders especially in peacemaking and peacebuilding processes.

\section{Recommendation}

Meaningful participation of women is crucial to the effectiveness of all peace and security interventions. Thus, enhancing women's involvement in peacemaking as well as post-conflict peacebuilding in Africa was an imperative that the national and international bodies should continue to support. This could be done by creating a platform for women across all levels of African societies to exchange, share and harmonize strategies and while building coalitions. Governments across African states should also strife to establish a gendered peace-focused centre that would carry out specialized research and training on the roles of women before, during and after conflict and how these roles interfere in their peacemaking and peacebuilding activities among other issues.

The conventional impression of women as helpless victims of wars should be replaced by the important role of women in fostering peace and security. That too, should not be done from the perception of what women can sacrifice for peace alone, but also, what peace translates for women.

\section{References}

Agatha, M. (2006).The Role of Women in Peace building and Conflict Resolution in African Traditional Societies.Retrieved from: http//www.afrikaworld.net

Agbaje, F.I. (2017). Tribunals as Instruments for Peacemaking among Ekiti Women in Traditional Settings in Southwestern Nigeria. International Journal of Advanced and Multidisciplinary Social Science, 3(3), 5566. doi:10.5923/j.jamss.20170303.01

Anderlini, S. N. (2000). Women at the peace table: Making a difference. UNIFEM

Anderlini, S.N., 2007, Women Building Peace: Why They Do It, Why It Matters. Boulder: Lynne Rienner Publishers.

Aroussi, S. (2011). Women, Peace and Security: Addressing Accountability for Wartime Sexual Violence. International Feminist Journal of Politics, 13 (4), 576-593. London: Routledge.

Babbie, E. \& Mouton, J. (2001).The practice of social research. Cape Town: Oxford University Press.

Gizelis, T.I. (2011). A Country of their Own: Women and Peacebuilding. Conflict Management and Peace Science, 28 (5), 522-542. California:Sage Publications.

Bertolazzi, F. (2010). "Women with a blue helmet: the integration of women and gender issues in UN peacekeeping missions" UN-INSTRAW: Working Paper Series

Copelon, R. (1993). 'Surfacing Gender: Reconceptualizing Crimes Against Women in Time of War', in Bestman, C. (ed.), Violence: a Reader. London: Palgrave Macmillan.

Diaz, P.C. (2010) 'Women's Participation in Peace Negotiations: Connections between Presence and Influence', $1325+10$ : Women Count for Peace. New York: UNIFEM.

Enloe, C. (2005). 'What if Patriarchy is “the Big Picture”? An Afterword', in Mazurana, D., Raven-Roberts, A. and Parpart, J. (eds.), Gender, Conflict and Peacekeeping. Maryland: Rowman\& Littlefield.

Epstein, C. F. (1981). Women in Cynthia Fuchs Epstein.World Encyclopedia. London: World Books Childcraft International Inc.

Gnanadason A, Kanyoro, M.R.A. \& McSpadden, L.A. (2005).Women, Violence and Non-violent Change. Switzerland: WCC Publications.

Lederach, J.P (1997). Building Peace: Sustainable Reconciliation in Divided Societies Washington D.C.: United States Institute of Peace.

Kure, Z.A. (2010). The Guardian Nigerian Newspaper, Sunday, 14 March 2010, 16P.

Meintjes, S., Pillay, A., Turshen, M., 'There Is No Aftermath for Women' in Meintjes, S., Pillay, A., Turshen, M., (Eds.), The Aftermath: Women in Post-Conflict Transformation. London: Zed Books.

Mutunga, E. (2005). Gender and Peace Process in Africa. Ibadan: Spectrum Books Limited. 
Onslow, C \&, Schoofs, S. (2010). Peacebuilding with a gender perspective: How the EU Can Make a Difference, Synthesis Report. Brussels: International Alert/Initiative for Peace Building.

Pankhurst, D. (2000). Women, Gender and Peacebuilding. Working Paper 5, Centre for Conflict Resolution, Bradford: Department of Peace Studies, University of Bradford.

Pankhurst, D. (2008). 'Post-War Backlash Violence against Women: What Can Masculinity Explain?' in Donna, P (ed.), Gendered Peace: Women's Struggles for Post-War Justice and Reconciliation. London: Routledge.

Puechguirbal, N., 2010, 'Discourses on Gender, Patriarchy and Resolution 1325: A Textual Analysis of UN Documents', in International Peacekeeping, 17 (2)172-187.London: Routledge.

Robbin S.P. \& Judge, T.A. (2009).Organizational behavior. London: Pearson Education Ltd.

Robbin, S.P., Odendaal, A. \&Roodt, G. (2003). Organizational behaviour: Global and Southern African Perspectives. Cape Town: Pearson Education South Africa.

Ruddick, S. (1989).Maternal Thinking, Toward a Politics of Peace. New York: Ballantine Books.

Strickland, R. \&Duvvury, N. (2003). Gender Equity and Peacebuilding, From Rhetoric to Reality: Finding the Way. Washington: International Center for Research on Women.

Sudarkasa, N. (2005). "The status of women in indigenous African societies", in Andrea C. (ed.), Readings in gender in Africa. Indiana: Indiana University Press.

United Nations (2000).United Nations Security Council Resolution (S/RES/1325).Retrieved from: http://www.un.org/events/res_1325e.pdf .

\section{Biographical Statement}

Funmilayo Idowu Agbaje, 1981. Ph. D Peace and Conflict Studies, University of Ibadan (2016).Research Fellow at the Institute of Peace and Strategic Studies, University of Ibadan, Nigeria. Current areas of academic interest are Gender, Peacemaking, Peace-building, Conflict Management, Disaster Risk Management, Negotiation and Social Sector Management. Most recent journal article: Agbaje, F.I. (2017). Tribunals as Instruments for Peacemaking among Ekiti Women in Traditional Settings in Southwestern Nigeria. International Journal of Advanced and Multidisciplinary Social Science, 3(3), 55-66. doi:10.5923/j.jamss.20170303.01 